\title{
FEMINISME EKSISTENSIALISME DALAM NOVEL LAUT BERCERITA KARYA LEILA S. CHUDORI
}

\section{EXISTENSIALISM FEMINISM AS REFLECTED THROUGH THE NOVEL LAUT BERCERITA BY LEILA S. CHUDORI}

\author{
Dedy Eko Aryanto \\ UIN Syarif Hidayatullah Jakarta \\ Pos-el: ekoaryanto17@gmail.com
}

\begin{abstract}
This research aims to describe the position of women in several events that are reflected in the novel Laut Bercerita by Leila S. Chudori. The novel Laut Bercerita was chosen for analysis because it illustrates the complex position and struggle of the female characters in it who tried to equalize gender rights in the social strata which at that time reflected a precarious situation before the 1998 reform. The analysis of feminist elements in the novel Laut Bercerita is qualitative and presented descriptively using data in the form of words, sentences, accompanied by explanations that reflect aspects of existential feminism that appear in the novel. Based on the results of data analysis, this study produces the following conclusions: (1) the position of women in the novel Laut Bercerita has a big role in the journey of the main character of the Biru Laut, (2) profeminis bring up the unique fact that men apparently also play an important role in fighting for gender equality.
\end{abstract}

Keywords: feminism; existensialism; Laut Bercerita.

\begin{abstract}
Abstrak
Penelitian ini bertujuan untuk mendeskripsikan kedudukan perempuan pada beberapa peristiwa yang tecermin dalam novel Laut Bercerita karya Leila S. Chudori. Novel Laut Bercerita ini dipilih untuk dianalisis karena menggambarkan secara kompleks kedudukan dan perjuangan tokoh-tokoh perempuan di dalamnya yang mencoba menyamakan hak gender dalam strata sosial yang saat itu mencerminkan keadaan yang genting sebelum terjadinya reformasi 1998. Analisis unsur feminisme dalam novel Laut Bercerita ini bersifat kualitatif dan disajikan secara deskriptif dengan menggunakan data berupa kata dan kalimat disertai penjelasan yang mencerminkan aspek feminisme eksistensial yang muncul dalam novel. Berdasarkan hasil analisis data, penelitian ini menghasilkan kesimpulan sebagai berikut: (1) kedudukan perempuan dalam novel Laut Bercerita memiliki peran besar dalam perjalanan tokoh utama Biru Laut, (2) profeminis memunculkan fakta unik bahwa kaum lelaki ternyata juga berperan penting dalam memperjuangkan kesetaraan gender.
\end{abstract}

Kata-kata kunci: feminisme; eksistensialisme; Laut Bercerita.

\section{PENDAHULUAN}

Berbagai pengertian ilmu sastra telah dirumuskan secara sederhana dan luas oleh pakar sastra. Pengertian ilmu sastra secara sederhana dan luas itu dapat ditemukan dalam beberapa buku, baik kamus, ensiklopedia maupun referensi sastra. Pada 9 Jawaban Sastra Indonesia, Mahayana menjelaskan bahwa ilmu sastra ialah ilmu yang menyelidiki 
kesusastraan dengan berbagai masalahnya secara ilmiah (Purba, 2010: 1). Karya sastra merupakan wadah seni yang menampilkan keindahan lewat penggunaan bahasa yang menarik, bervariasi, dan penuh imajinasi (Keraf, 2002: 115).

Sapardji Djoko Damono mengatakan bahwa dunia sastra sangat berkembang dan tidak dapat lepas dan sangat mengikuti perubahan atau pengaruh yang ada pada masyarakat (Damono, 1983: 17). Karya sastra merupakan struktur yang kompleks. Oleh karena itu, untuk memakai karya sastra harus karya sastra tersebut yang dianalisis. (Suntini, Yoce, 2009: 157).

Beberapa pengertian tersebut dapat kita kerucutkan bahwa karya sastra erat hubungannya dengan permasalahan yang terjadi pada saat itu, sesuai dengan perkembangan zamannya. Pada saat zaman penjajahan, refleksi yang dituangkan pada setiap karya sastra baik puisi maupun prosa. selalu berhubungan dengan makna perjuangan. Tema yang diangkat selalu tentang penjajahan, perjuangan, dan kemerdekaan.

Berbicara tentang novel, tentu saja banyak novel yang merefleksikan kejadian di setiap zamannya. Novel merupakan prosa yang sangat kompleks, cerita didukung oleh adanya tokoh-tokoh dalam menampilkan alur cerita, dan latar yang tersusun baik sehingga pesan tersampaikan kepada pembaca (Sangidu, 2004: 55).

Novel Laut Bercerita menceritakan masalah sosial, membela keadilan, pemberontakan, bahkan kekejian yang terjadi pada masa lalu. Novel karya Leila S. Chudori ini sangat menarik karena secara tidak langsung, Leila menyinggung pemerintah pada saat itu perihal orang yang hilang bahkan sampai sekarang tidak ditemukan. Selain itu, hal yang sangat menarik ialah mengenai peran lakilaki dalam kesuksesan seorang perempuan, penyemangat hingga pemberi cinta yang paling tulus.

Penelitian ini akan membahas novel Laut Bercerita karya Leila S. Chudori dari sudut pandang feminisme eksistensialisme karena kita ketahui bahwa seorang perempuan memiliki support system.

Penelitian terdahulu mengenai Laut Bercerita selalu terfokus pada hal-hal yang berbau sosial, seperti "Realitas Sosial dalam Novel Laut Bercerita Karya Leila S. Chudori: Analisis Strukturalisme Genetik" karya Ema Zuljiyani Sembada dan Maharani Intan Andalas (Jurnal Sastra Indonesia UNNES Vol. 8 No 2 Juli 2019). Penelitian tersebut membahas realitas sosial dengan pembuktian bahwa telah ditemukan realitas sosial dalam novel melalui hubungan antartokoh dalam novel serta hubungan tokoh dengan objek yang ada di sekitarnya. Penelitian selanjutnya berjudul "Analisis Psikologi Sastra dan Nilai Pendidikan Karakter Novel Laut Bercerita Karya Leila S. Chudori Serta Relevansinya sebagai Bahan Ajar Apresiasi Sastra di SMA" karya Ansy Rachmat Setiawan, Kundharu Saddhono, dan Raheni Suhita, Jurnal BASASTRA Vol. 7 No 1 April 2019). Penelitian tersebut membahas energi psikis dan naluri yang menekan manusia agar memenuhi kebutuhan dasar, seperti makan dan seks menolak rasa sakit atau tidak nyaman.

Perbedaan penelitian ini dengan kedua penelitian tersebut adalah pembahasan yang. Peneliti membongkar tokoh wanita yang terdapat dalam novel Laut Bercerita sebagai bahasan pokok tentang feminisme eksistensialisme. Dalam pembahasan ini kita dapat melihat bahwa para lelaki sangat berperan penting dalam kesuksesan perempuan. Permasalahan ini muncul karena tokoh laki-laki dalam novel tersebut terlihat sangat berpengaruh pada jalan cerita, sedangkan tokoh perempuan hanya berpengaruh secara tidak langsung dalam ceritanya.

\section{LANDASAN TEORI}

Feminisme merupakan teori mengenai persamaan hak antara laki-laki dan perempuan di bidang politik, ekonomi, dan sosial, atau kegiatan 
terorganisasi yang memperjuangkan hak-hak serta kepentingan perempuan (Nurgiyantoro, 2007: 59).

Feminisme eksistensialis percaya bahwa perempuan bukan mengagungkan konsep liyan, tetapi konsep diri seperti laki-laki. sehingga apa yang diterapkan pada laki-laki juga bisa diterapkan pada perempuan. Feminisme ini muncul sebagaimana pengembangan aliran filsafat eksistensialisme yang dikembangkan oleh Jean Paul Sartre dengan konsep yang paling dekat dengan feminisme eksistensialisme, yaitu pandangan dirinya mengenai eksistensi manusia, etre-pour-les autres atau ada untuk orang-orang lain. Selanjutnya, konsep ini mengoreksi tiga pendapat mengenai perbedaan laki-laki dan perempuan yang telah ada sebelumnya, yaitu biologi, psikologi, dan ekonomi.

Feminisme eksistensialisme memperjuangkan eksistensi perempuan yang seakan-akan terikat oleh norma dan kebudayaan tetap, seperti pernikahan. Menurut Beauvoir, perkawinan merupakan bentuk sedimentasi eksistensi perempuan, terlebih menjadi seorang ibu, karena perempuan akan mudah sekali dibatasi haknya dalam bermasyarakat (Tong, 1994: 126). Selanjutnya, penyampaian pendapat mengenai ontologisme yang berdasarakan pada being 'ada'. Ia melihat eksistensi perempuan sebagai jati diri yang diartikan lakilaki. Menurut pandangan laki-laki, eksistensi orang lain dianggap sebagai sebuah ancaman. Untuk menjaga agar laki-laki tetap dapat menjaga maka perlu diciptakan mengenai mitos laki-laki terhadap perempuan. Mitos yang nantinya melahirkan sebuah peraturan, tradisi, bahkan kebudayaan yang mayoritas menganggap perihal perempuan mempunyai suatu tugas mengorbankan diri untuk lakilaki. Meskipun tahu citra buruk ini, perempuan tidak akan dapat membebaskan diri karena lakilaki mempunyai suatu kekuasaan atas dirinya. Ironisnya, perempuan sendiri meyakini tentang fungsi ini (Purnomo, 2017: 317-318).
Beauvoir menjelaskan bahwa kontruksi sosial merupakan permasalahan utama mengenai mekanisme subjek mengontrol diri perempuan. Selain itu, peran mengenai stereotip perempuan diterima dan diturunkan kepada perempuan kepada generasi selanjutnya. Oleh sebab itu, Beauvoir menerapkan konsep feminisme eksistensialis, yakni seorang perempuan akan memperjuangkan kedudukannya dalam struktur sosial. Bukan semata-mata untuk menentang ataupun menghancurkan strata sosial yang terbentuk melalui kekuatan patriarkal laki-laki, tetapi, lebih dari itu, perempuan berhak untuk dirinya sendiri dan dapat melakukan apapun yang ia anggap perlu bagi dirinya sendiri tanpa harus ada intervensi atau campur tangan dari orang lain.

Penelitian feminisme eksistensialisme belum pernah dilakukan terhadap novel Laut Bercerita, tetapi terhadap novel Leila S. Chudori yang berjudul Pulang banyak yang melakukannya. Referensi yang paling relevan dalam pembahasan feminisme eksistensialis adalah buku Rosemarie Putnam Tong, dalam Feminist Thought: Pengantar Paling Komprehensif kepada Arus Utama Pemikiran Feminis karya Mulyo Hadi Purnomo, yang berjudul "Melawan Kekuasaan Laki-laki: Kajian Feminis Eksistensialis Perempuan di Titik Nol Karya Nawal El-Saadawi" dalam jurnal NUSA Universitas Dipenegoro.

\section{METODE PENELITIAN}

Penelitian ini adalah penelitian kualitatif dengan metode deskriptif. Muhammad (2011: 19) menjelaskan bahwa penelitian kualitatif ialah penelitian yang mengembangkan pengertian tentang individu dan kejadian dengan memperhatikan konteks yang relevan. Metode deskriptif merupakan metode yang digunakan untuk mendeskripsikan informasi tertentu. Analisis deskriptif ini digunakan untuk mendeskripsikan bentuk-bentuk 
feminisme eksistensialisme yang terdapat pada novel Laut Bercerita (Anggoro, 2007: 65).

Data dalam penelitian ini ialah kalimat-kalimat yang berbentuk dialog, monolog, maupun narasi yang berhubungan dengan feminisme eksistensialisme dalam novel Laut Bercerita. Penelitian ini bertindak sebagai human interest karena pada penelitian kualitatif, peneliti bertindak sebagai yang mengumpulkan data, sebagai subjeknya. Teknik pengumpulan data pada penelitian ini ialah peneliti membaca, memahami, mencatat, dan mengidentifikasi mengenai feminisme eksistensialisme dalam novel Laut Bercerita karya Leila S. Chudori. Tahapan analisis penelitian ini berdasarkan pada data yang dilakukan secara interkatif, yaitu reduksi data, penyajian data, dan kesimpulan.

\section{PEMBAHASAN}

Pada novel Laut Bercerita karya Leila S. Chudori, terdapat tiga karakter tokoh perempuan yang menonjol keberadaannya dan seakan-akan menjadi sosok yang selalu membuat tokoh utama Biru Laut terpana. Ketiga tokoh tersebut adalah Kasih Kinanti, seorang aktivis UGM dan merupakan ketua organisasi Winatra; Ratih Anjani, seorang aktivis Taraka sekaligus kekasih Laut; dan Asmara Jati, seorang dokter yang merupakan adik satu-satunya dari tokoh Biru Laut. Dalam novel ini, mereka memiliki berbagai kesamaan yang membuat tokoh Laut berulang kali mengatakannya,

"Cerita dimulai pada Rumah Susun Klender, 13 Maret 1998, Kinan dan Anjani memberikan pembukaan pemikiran mengenai feminisme. Biru Laut berkata, jika bukan karena kalian bertiga, aku tidak akan sadar bahwa perempuan merupakan pencipta kebidupan peniup ruh, serta penggerak matahari dalam kegairahan hidup” (Laut Bercerita, 2017: 220).
Tampak pada kutipan di atas, tokoh Laut menyadari kekuatan feminisme yang ditonjolkan oleh ketiga sosok itu, yakni Kinan, Asmara, dan Anjani telah menjadi sosok yang menginspirasi bagi Laut mengenai kekuatan seorang perempuan dalam meletupkan segala emosi melalui cara-cara tak terduga,

"Penyesalan atau bubungan antara sang kekeasih, perkataan mendambakan dilontarkan, setiap langkah yang telah dijalankan, entah apakah terasa atau tidak, hal tersebut merupakan kontribusi. Mungkin saja jika kita pergi dari rezim ini sekitar 10 atau 20 tabun yang akan datang, tapi apapun yang dialami di Blangguan serta Bungurasib merupakan jalan atau langkeah yang telah kita tempuh, sebuah kalimat indah pada cerpenmu dan sebuah baris puisi indah pada karyamu” (Laut Bercerita, 2017: 198).

Kutipan di atas menunjukkan hubungan secara langsung antara Laut dengan Asmara, Kinan, dan Anjani. Ketiga tokoh di atas menggambarkan bahwa mereka lebih cakap, lebih peka, dan lebih tanggap dari sosok laki-laki yang diekspos pada diri Biru Laut. Kutipan di atas menggambarkan secara ringkas bahwa Leila S. Chudori adalah pegiat feminisme yang melalui novelnya ditonjolkan pada posisi tokoh perempuan yang selalu menjadi sosok pemecah masalah yang dihadapi oleh tokoh laki-laki.

Saat bersama Anjani, tokoh Laut terlalu terpesona dengan kecantikan pantai pasir putih Situbondo dan wajah mungil Anjani sehingga ia tidak sadar bahwa di sekitarnya ada intel yang siap siaga mendengarkan sepatah dua kata yang diucapkan oleh Laut. Anjani pun menjadi sosok penolong dengan berinisiatif menutup mulut Laut yang saat itu berbicara mengenai situasi di Blangguan dengan mencium Laut untuk mengalihkan perhatian para intel. Saat bersama Kinan, tokoh Laut pun hampir menuju titik keputusasaan setelah ia dan Julius disiksa dan diinterogasi oleh aparat di 
Surabaya. Namun, Kinan memberikan semangat sentimental kepada Laut dengan menganggap sedikit saja mereka bergerak, maka tetap saja itu merupakan sebuah kontribusi, sehingga kekuatan dan keberanian tokoh Biru Laut pun kembali seperti sediakala. Saat bersama Asmara, tokoh Laut yang sedikit demi sedikit meninggalkan dunia kampus dan beralih ke dunia aktivis pun selalu dinasihati oleh Asmara dan Asmara pun siap mengorbankan jiwa raganya untuk mengantarkan skripsi Laut dan Alex agar segera diberikan kepada dosen pembimbing mereka di Yogyakarta. Peristiwa ini mengindikasikan seberapa superior kaum perempuan dalam novel Laut Bercerita yang eksistensinya selalu menjadi oase bagi keputusasaan tokoh laki-laki. Tokoh laki-laki, walaupun diceritakan sebagai sosok yang dominan dalam novel ini, tetapi mereka memiliki summit point (titik puncak) di dalamnya sehingga apabila mereka menyentuh titik itu, sukar baginya untuk kembali ke sediakala. Di sinilah hadir sosok-sosok perempuan yang sebelumnya hanya menjadi figuran belaka, menjadi sosok sentral yang membangkitkan tokoh laki-laki mengatasi summitpoint--nya dan kembali menjadi dirinya seperti sediakala.

\section{Paham Feminisme Eksistensialsme}

Menurut referensi mengenai feminisme eksistensialis di atas, peneliti dapat menganalisis peran tokoh pejuang hak perempuan yang terdapat dalam novel Laut Bercerita karya Leila S. Chudori ini dalam dua pihak, yaitu pihak yang merupakan penganut paham feminisme eksistensialis serta paham feminisme lain (liberal, sosialis, radikal). Paham feminisme eksistensialisme dapat dilihat pada kutipan-kutipan novel sebagai berikut.

"Hal yang paling menyebalkan dalam persaudaraan ialab memiliki tiga orang kakak laki-laki dan ayabku cukup dominan, mungkin karena aku tumbuh pada lingkungan itu, hal yang terjadi pada hawa lingkungan ini ialah suasana maskulin yang sangat berlebihan, tentu saja lah itu wajar terjadi pada keluarga yang mayoritas laki-laki, hal yang sangat aku banggakan adalah, mereka sangat menyanyangi adik bungsunya ini, karena adik bungsu satusatunya perempuan, lebih tepat lagi kakakkakak.ku membuat teman laki-lakiku menjauh ketakutan" (Laut bercerita, 2017: 105-106).

Tokoh Anjani pada kutipan di atas menggambarkan bahwa masa mudanya selalu dibayangbayangi oleh ketiga kakak lelakinya. Ia menganggap kelakuan kakak-kakaknya selalu mengintimidasi keinginan-keinginan Anjani yang selalu terpendam. Oleh sebab itu, Anjani pun berusaha menunjukkan bahwa dirinya mampu hidup secara mandiri tanpa harus selalu diawasi oleh kakakkakaknya yang ia anggap terlalu protektif bagi dirinya dengan berkuliah di tempat yang jauh dari keluarga.

"Perbatian yang muncul dari mas Indra kepadaku, padahal mas Indra kuliah di Bandung, dan aku di Jakarta, tetapi hampir setiap hari mas Indra mengecek aku, berbeda dengan mas Raka dan mas Mahesa, mereka sangat menjengkelkan karena mereka telah mencoba meyakinkan orang tua kami bahwa Yogyakarta merupakan ide buruk, padahal ISI Yogyakarta merupakan pilihan pertamaku. Selain masalah lokasi, aku juga akan menjelaskan mengenai pemilihan jurusanku yang tertuju pada seni rupa, tidak dengan jurusan lain." (Laut bercerita, 2017: 106-107).

Tampak pada kutipan di atas bahwa tokoh Anjani berjuang untuk menunjukkan bahwa dirinya bisa, dengan eksistensinya sebagai perempuan bukanlah sebuah masalah apabila ia ingin mencapai suatu tujuan. Ia pun berteguh hati untuk dapat melanjutkan studinya ke Yogyakarta yang notabene jauh dari pengawasan kakak-kakaknya. Selain itu, tokoh Anjani berusaha menunjukkan bahwa kemampuan menggambar yang ia miliki bukanlah semata-mata coretan di atas dinding belaka, tetapi ia yakin apa yang ia buat merupakan sebuah mahakarya yang pantas dibanggakan oleh 
keluarganya, khususnya kakak-kakaknya. Setelah berjuang menunjukkan eksistensinya, perjuangan tokoh Anjani pun tidak sia-sia. Ia pun diberi restu untuk melanjutkan studi seninya ke Yogyakarta. Lebih dari itu, perjuangan yang dilakukan oleh Anjani tidak lepas dari dukungan keluarga yang selalu membantunya.

Sesuai dengan teori yang disampaikan oleh Beauvoir, bahwa feminisme eksistensialis bukan hanya menitikberatkan pada peran seorang perempuan yang berjuang menghadapi patriarki, tetapi, juga pada kesadaran laki-laki dan membantunya dalam mengupayakan kesetaraan kelas antara lakilaki dan perempuan yang diinginkan. Keinginan Beauvoir pun seolah-olah tecermin di dalam kisah Ratih Anjani, seorang bungsu dan merupakan satusatunya perempuan dari empat bersaudara. Ia menghadapi segala bentuk protektif yang dilakukan oleh kakak-kakaknya, ia pun sadar dan berusaha berjuang untuk melepaskan diri dan menganggap bahwa dirinya mampu untuk berdiri di atas kaki sendiri. Inilah yang paling utama, bahwa kakak-kakaknya mendukung secara fisik, moral, maupun verbal atas segala upaya yang dilakukan oleh Anjani. Kisah Anjani ini pun mencerminkan feminisme eksistensialis yang global dan beradab.

\section{Wujud Nyata Perjuangan}

Tokoh lain di dalam novel Laut Bercerita karya Leila S. Chudori yang terindikasi oleh peneliti menganut paham feminisme eksistensialis adalah tokoh dua madres asal Argentina yang tidak pernah berhenti menyuarakan keberadaan anak-anaknya yang hilang diculik oleh diktator,

"Tahun lalu aku berhasil melakukan perjuangan ketika dua madres yang sangat dahsyat berbicara tentang semangat dan fasih karena ini merupakan teror dan sebuah kekejian yang sudah dilakukan di seluruh dunia, jelasnya pada pemerintahan diktator. Daniel dan Alex mewakili komisi yang memberi testimoni dan mendukung konvensi pengesahan di New York, merupakan kemenangan besar bagi kamu.
Tentu saja kami merayakannya dengan mangkok ramen kedua yang aku pesan, jika saja aku take berjanji bertemu dengan ibu, pasti kami akan memesan sake" (Laut bercerita, 2017: 354).

Tampak pada kutipan di atas secara tersirat bagaimana perjuangan kekuatan perempuan yang diwakili oleh para ibu-ibu mengacak-acak diktator yang berkuasa saat itu untuk menjelaskan nasib anak-anak mereka yang hilang diculik tanpa tahu keberadaan dan kondisinya. Para ibu itu pun membentuk sebuah agenda mingguan, yakni mereka akan berjalan mengelilingi istana kepresidenan Argentina setiap hari Kamis sebagai bentuk kegigihan mereka dalam mengetahui informasi anakanak mereka yang hilang entah ke mana. Perjuangan yang didasari oleh sikap sama rasa oleh Alex dan Daniel terhadap nasib ibu-ibu asal Argentina itu pun berhasil menurunkan konvensi perdamaian PBB yang merupakan babak baru dalam terciptanya iklim demokrasi yang seadil-adilnya bagi negara-negara anggota PBB, termasuk Argentina dan Indonesia.

"Aturan mereka sangat aneh, tidak boleh berkumpul lebih dari dua orang di depan istana, Fiorella berkata menggunakan aksen Hispantik yang kental dan suara yang berat dan tentu saja serak. Fiorella bertubub besar dan tampak tegap, dua madres maju jalan kemudian lenyap, menyusul kedua madres tersebut, ba ba ha lama-lama kami berbaris dan polisi tidak bisa melakukan apa-apa dengan siasat kami, dia mengenang peristiwa 1978 silam" (Laut bercerita, 2017: 356).

Kedua tokoh madres di atas, Oma Fiorella dan Oma Malena merupakan wujud nyata perjuangan seorang perempuan yang mengindahkan risiko apapun demi menunjukkan kepada pemerintah diktator Argentina bahwa mereka berani, mereka siap dengan apaun, mereka pantang menyerah, dan mereka tidak pernah takut untuk menuntut pemerintah agar memberitahukan kondisi anak-anak 
mereka. Wujud eksistensi yang coba diterapkan oleh para madres di Argentina ini merupakan pola baru demonstrasi yang selanjutnya banyak diterapkan di negara-negara lain yang pernah dilanda permasalahan yang sama, termasuk Indonesia. Pola demonstrasi yang memiliki bentuk bukan seperti demonstrasi, tetapi diterapkan secara intens, tanpa harus mendatangkan banyak orang. Cukup sedikit orang, tetapi mereka memiliki rasa yang sama, keprihatinan yang sama, dan keinginan yang sama, bahwa demokrasi seburuk apapun, harus tetap diwujudkan, bagaimanapun bentuknya.

Perjuangan yang coba dilakukan oleh para madres adalah perjuangan yang kental dengan prinsip feminisme eksistensialis. Keberadaan mereka yang sebelumnya tidak dianggap oleh pemerintah berkuasa yang secara tersirat merupakan 'laki-laki', tetapi dengan perjuangan yang intens, murni, dan tidak pernah putus membuahkan hasil. Gerakan mereka mulai dilirik oleh organisasi kemanusiaan. Wartawan asing pun mulai meliput aksi mereka. Tindakan-tindakan yang makin besar sehingga membuat pemerintah tidak kuasa menahan pertanyaan rakyatnya. Akhirnya, pemerintah pun berinisiatif untuk menyelidiki secara tuntas penghilangan secara paksa anak-anak para madres. Walaupun hasilnya mengecewakan, karena yang ditemukan hanyalah makanan anak-anaknya, tetapi bukan itu esensi perjuangan para madres. Sebagai seorang perempuan, para madres berhasil menghapus stigma perempuan sebagai liyan, yang merupakan warga kelas dua, dengan berhasilnya mereka menggalang kekuatan secara penuh agar kekuatan patriarki tumbang, dan kebenaran kebenaran demokrasi berhasil ditegakkan.

Wujud feminisme yang ditunjukkan oleh para madres bahwa perempuan adalah diri dan memiliki hak yang sama sebagaimana laki-laki miliki.

\section{SIMPULAN}

Pemikiran Beauvoir mengenai feminisme telah terealisasi oleh Leila melalui dua karakter pada novel Laut Bercerita ini. Konsep feminisme eksistensialisme telah berdiri tegak melalui tokoh Anjani dan para madres dari Argentina.

Berdasarkan uraian di atas, tampak jelas bahwa novel Laut Bercerita merupakan suatu wujud novel yang mencampurkan antara realitas faktual dan realitas ideal. Realitas faktual yang dimaksud adalah kehidupan awal para karakter perempuan dalam novel, sedangkan realita ideal adalah konsep Simone de Beauvoir mengenai feminisme eksistensialisme. Sikap ini dapat dipahami sebagai usaha Leila sebagai tokoh feminisme untuk memperjuangkan cita-citanya. Kejadian yang nyata dimanfaatkan untuk menarik perhatian yang dimiliki perempuan lain untuk menjadi lebih terdorong menegakkan sebuah eksistensi yang telah terebut oleh budaya patriarki. Realitas ideal telah disisipkan untuk memberikan cara alternatif kepada perempuan dan menyadarkan masyarakat untuk menuju suatu perjuangan dan sebuah penghargaan perempuan.

\section{DAFTAR PUSTAKA}

Andalas, Maharani Intan dan Ema Zuljiyani. 2019. "Realitas Sosial dalam Novel Laut Bercerita Karya Leila S. Chudori: Analisis Strukturalisme Genetik". Dalam Jurnal Sastra Indonesia UNNES Vol. 8 No 2. Juli.

Chudori, Leila S.. 2017. Laut Bercerita. Jakarta: PT Gramedia Pustaka Umum.

Damono, Sapardji Djoko. 1983. Kesusasteraan Indonesia Modern. Jakarta: Gramedia.

Darma, Yoce Aliah. 2009. Analisis Wacana Kritis. Bandung: Yrama Widya.

Keraf, Gorys. 2002. Diksi dan Gaya Bahasa. Jakarta: Gramedia Pustaka Umum. 
Muhammad. 2011. Metode Penelitian Bahasa. Sartre, Jean Paul. 2002. Eksistensialisme dan Jogjakarta: Gadjah Mada. Humanisme. Yogyakarta: Pustaka Pelajar.

Muzairi, H. 2002. Filsafat Ekesistensialisme Jean Paul Suhita, Raheni, Ansy Rachmat Setiawan, dan Sartre. Yogyakarta: Pustaka Pelajar. Kundharu Saddhono. 2019. "Analisis

Nurgiyantoro, Burhan. 2012. Teori Pengkajian Fiksi. Psikologi Sastra dan Nilai Pendidikan Yogyakarta: Gadja Mada University Press.

Purba, Antilan. 2010. Sastra Indonesia Kontemporer. Yogyakarta: Graha Ilmu.

Purnomo, Mulyo Hadi. 2017. "Melawan Kekuasaan Laki-Laki; Kajian Feminis Eksistensialis "Perempuan di Titik Nol"Karya Nawal el-Saadawi”. Dalam Jurnal Undip. Vol. 12. No. 4 November Karakter Novel Laut Bercerita Karya Leila S. Chudori serta Relevansinya sebagai Bahan Ajar Apresiasi Sastra di SMA". Dalam Jurnal BASASTRA Vol. 7 No 1. April.

Toha, Anggoro. 2007. Metodologi Penelitian. Jakarta: Universitas Terbuka.

Tong, Rosmarie Putnam. 1994. Feminist Thought: Pengantar Paling Komprehensif kepada Aliran Utama Pemikiran Feminis. Yogyakarta: Jalasutra.

Budaya UGM. 


\title{
PERJODOHAN DAN ISU EKOKRITIK DALAM METROPOP DIMI IS MARRIED KARYA RETNI SB
}

\section{MARRIAGE ARRANGED AND ECOCRITICISM'S ISSUES IN THE METROPOP DIMI IS MARRIED BY RETNI SB}

\author{
Tania Intan ${ }^{1,}$ Prima Agustina Mariamurti ${ }^{2,}$ Nurul Hikmayaty Saefullah ${ }^{3}$ \\ ${ }^{1,2}$ Departemen Susastra dan Kajian Budaya, Universitas Padjadjaran \\ ${ }^{3}$ Departemen Linguistik, Universitas Padjadjaran \\ Pos-el: tania.intan@unpad.ac.id
}

\begin{abstract}
This research was aimed at uncovering the matchmaking phenomenon and ecocritical issues in Retni SB' metropop novel Dimi is Married (2015). The method used in this research was descriptive qualitative with feminist literary criticism and ecocritical approaches. Data in the form of words, phrases, and sentences from the object of analysis were collected using the note-taking technique after going through closed reading. The data was then classified based on the problem, interpreted, and analyzed by relevant theories. The results showed that matchmaking was mediated by both parents with the motive of maintaining "nobility" in a modern context. Matchmaking was carried out by applying considerations to traditional criteria, namely heredity, social status, and self-quality. The standard of women who were desired as potential wives is following the stereotype of gender roles, namely having a sweet, polite, obedient, and loving character to their parents. Matchmaking problems occurred because of the inhomogeneous relationship between partners concerning reasons for marriage, social status, and outlook on life. The ecocritical issues discussed in the novel involved elements of forests, disasters, animals, and the earth. Women spoke out about the damage to nature and the lost suffered by local people due to industrial management that neglected the environment. In a feminist view, patriarchal ideology works through the treatment of nature that resembles the actions of women, namely as objects of exploitation.
\end{abstract}

Keywords: marriage arranged, ecocriticism issues, metropop

\begin{abstract}
Abstrak
Penelitian ini ditujukan untuk mengungkap fenomena perjodohan dan isu ekokritik dalam novel metropop Dimi is Married (2015) karya Retni SB. Metode yang digunakan dalam penelitian ini adalah deskriptif kualitatif dengan pendekatan kritik sastra feminis dan ekologi sastra. Data berupa kata, frasa, dan kalimat dari objek penelitian dikumpulkan dengan teknik simak-catat setelah melalui pembacaan tertutup. Data kemudian diklasifikasi berdasarkan permasalahan, diinterpretasi, dan dianalisis dengan teori-teori yang relevan. Hasil penelitian menunjukkan bahwa perjodohan diperantarai oleh kedua orang tua dengan motif menjaga "keningratan" dalam konteks modern. Perjodohan dilakukan dengan menerapkan pertimbangan atas kriteria tradisional, yaitu bibit, bebet, dan bobot. Standar perempuan yang diinginkan sebagai calon istri adalah yang sesuai dengan stereotipe peran gender, yaitu berkarakter manis, sopan, patuh, dan sayang pada orang tua. Permasalahan dalam perjodohan terjadi karena relasi yang tidak homogen di antara pasangan berkaitan dengan alasan menikah, status sosial, dan pandangan hidup. Isu ekokritik yang dibahas dalam novel melibatkan elemen hutan, bencana, binatang, dan bumi. Perempuan menyuarakan kerusakan alam dan kerugian yang dialami rakyat lokal akibat pengelolaan industri yang abai pada lingkungan. Dalam pandangan feminis, ideologi patriarki bekerja melalui perlakuan manusia terhadap alam yang menyerupai tindakan laki-laki pada perempuan, yaitu sebagai objek eksploitasi.
\end{abstract}

Kata-kata kunci: perjodohan, isu ekokritik, metropop 


\section{PENDAHULUAN}

'Metropop' merupakan istilah yang dibentuk dari kata 'metropolitan' dan 'populer', yang diciptakan sekitar tahun 2000an oleh PT Gramedia Pustaka Utama untuk menandai salah satu produknya. Kemunculan metropop beriringan dengan meningkatnya jumlah karya fiksi populer yang ditulis oleh pengarang perempuan, seperti chick lit, teen lit, atau amore. Metropop adalah kisah romance yang menampilkan hubungan di antara tokoh utama perempuan dan laki-laki yang diwarnai dengan berbagai konflik, dilema, dan masalah percintaan khas masyarakat urban (Deona, 2019: 321). Fitriana (2010: 8-9) menjelaskan bahwa metropop selalu mengetengahkan kehidupan warga metropolitan masa kini dan ceritanya selalu berputar di sekitar percintaan, karir, dan gaya hidup modern dari para tokohnya.

Dalam novel metropop Dimi is Married (2015) karya Retni SB yang menjadi objek formal kajian ini, tema mayor yang diangkat adalah tentang perjodohan. Perjodohan sendiri merupakan fenomena yang dianggap tidak lagi lazim terjadi di era modern. Perjodohan juga dinilai kontraproduktif dalam perspektif feminis, karena dianggap kerap merugikan perempuan. Namun, ternyata perjodohan merupakan tema yang cukup sering didaur ulang di dalam fiksi populer (Fiksimetropop, 2014). Penulis biasanya akan menautkan dua karakter yang awalnya terhubung dengan keterpaksaan, ada ketidakcocokan, dan ada pembiasaan. Selanjutnya, kedua pihak yang dijodohkan tersebut akan saling jatuh cinta dan hidup bahagia selamanya.

Meskipun memiliki akhir yang mudah ditebak seperti itu, novel-novel dengan tema perjodohan ternyata diapresiasi kehadirannya, mulai dari sastra kanonik/serius, seperti Siti Nurbaya (1922) karya Marah Rusli dan Midah Si Manis Bergigi Emas (1954) karya Pramoedya Ananta Toer maupun di dalam karya-karya popular, seperti Jodoh Terakbir
(2010) karya Netty Virgiantini, Dongeng Sebelum Tidur (2018) karya Agnes Jessica, Gagal Move on (2018) karya Eriska Helmi, Eiffel I'm in Love (2003) karya Rachmania Arunita, Perempuan Jogja (2012) karya Achmad Munif, My Cold Wedding (2020) karya Nabila Poetri, Mahogany Hills (2013) karya Tia Widiana, Marriagable: Gue Mau Nikah Asal ... (2006) karya Riri Sardjono, Black Confetti (2014) karya Assrianti, Orange (2008) karya Windry Ramadhina, dan Summer Sky (2019) karya Stephanie Zen. Realita ini memperlihatkan bahwa perjodohan merupakan permasalahan yang masih dianggap menarik untuk dibincangkan.

Dalam penelusuran peneliti, telaah terhadap novel klasik bertema perjodohan, seperti Siti Nurbaya dan Memang Jodoh telah banyak dilakukan. Namun, kajian-kajian tersebut pada umumnya tidak benar-benar berfokus pada masalah perjodohan, kecuali yang telah dilakukan oleh Wicaksono (2015) terhadap novel Memang Jodoh. Penelitian dengan pendekatan sosiologi sastra tersebut menyimpulkan adanya permasalahan dalam perjodohan berlatar budaya Minangkabau tersebut. Masalah yang dimaksud dipicu oleh penentangan dari kaum muda terpelajar yang cenderung mengadopsi pemikiran Barat. Upaya yang dilakukan untuk menentang adat perjodohan ini diwujudkan tokoh utama dengan mengeksekusi perkawinan pantang, yang berarti menikah dengan masyarakat di luar sukunya. Kajian lainnya dilakukan Abadiyah (2020) yang menganalisis konflik perjodohan dalam novel Hati Subita karya Khilma Anis dengan pendekatan psikologi sastra. Kajian tersebut menunjukkan adanya konflik internal akibat perjodohan, yaitu perasaan kecewa, diabaikan, tidak dianggap, dan cemburu.

Perjodohan bukan satu-satunya tema yang diangkat di dalam metropop Dimi is Married karena novel tersebut juga ternyata berpusat pada isu ekokritik. Dalam khazanah sastra, gagasan tentang alam dan lingkungan hidup dianggap 
penting, khazanah itu banyak dieksplorasi dan kemudian diikuti dengan kajian terhadap teks-teks tersebut. Relasi antara manusia dan lingkungan hidup dalam novel Partikel karya Dewi Lestari telah dikaji oleh Ramadhani dan Sartuni (tanpa tahun). Simpulan dari analisis tersebut adalah bahwa pada hakikatnya, manusia dan alam merupakan satu kesatuan. Dalam kajian lainnya, Ulya dkk. (2020) mempelajari kumpulan cerpen Sepotong Senja untuk Pacarku karya Seno Gumira Ajidarma. Temuan dari penelitian yang menerapkan teori hermeneutika tersebut adalah adanya pesan untuk menjaga kebersihan lingkungan yang ditemukan pada beberapa cerita dalam kumpulan cerpen. Penelitian terhadap novel Lanang karya Yonathan Rahardjo dilakukan oleh Putra dan Sugiarti (2019) dengan pendekatan ekologi budaya. Penelitian tersebut mengungkapkan bahwa ada dinamika di dalam ekologi budaya yang digambarkan melalui tindakan manusia dalam memenuhi kebutuhannya, yaitu secara tradisional dan modern. Pemilihan salah satu cara dari keduanya akan melahirkan ketimpangan terhadap lingkungan. Kedua cara tersebut selayaknya dilakukan beriringan untuk mencapai ekologi budaya yang ideal. Pendekatan ekologi budaya juga digunakan oleh Sugiarti (2017) untuk membedah novel Tirai Menurun karya NH. Dini dengan berfokus pada fakta budaya dan tata nilai budaya Jawa. Penelitian tersebut mengungkapkan bahwa fakta budaya Jawa mencakup segala aktivitas tokoh terkait adat istiadat dalam fase kehidupan manusia, yaitu pernikahan, kehamilan, dan kematian. Tata nilai budaya Jawa dijadikan standar dalam menjalani hidup hingga diperoleh keselarasan.

Kritik sastra ekologis dilakukan oleh Andriyani dan Piliang (2019) yang mempelajari novel-novel kontemporer Indonesia dengan teori Garrard. Kajian tersebut membahas pencemaran, hutan belantara, bencana, perumahan, binatang, dan bumi. Novel yang dipilih untuk pembahasan kritik sastra ekologis adalah Luka Perempuan Asap karya Nafi'ah al-Ma'rab, Tanjung Kemarau karya Royyan Julian, dan Lelaki Harimau karya Eka Kurniawan. Telaah serupa kemudian dilakukan Andriyani (2020) untuk meneliti drama-drama kontemporer Indonesia. Naskah drama yang dikaji adalah Pasar Malam untuk Brojo karya Dhianita Kusuma Pertiwi, Arloji Saku dari Perak Bukan Orang Asing Wajahwajah karya Bakdi Soemanto, dan Tak Ada Bintang di Dadanya karya Hamdy Salad. Hasil penelitian tersebut memperlihatkan bahwa dalam drama kontemporer terkandung konsep sastra ekologis yang merupakan bentuk refleksi masyarakat dan pesan untuk menjaga lingkungan.

Pembahasan isu ekokritik dengan berfokus pada relasi perempuan dan lingkungan dibahas dalam kajian dengan pendekatan ekofeminisme. Ahmadi (2017) mengaitkan filsafat lingkungan dan ekofeminisme untuk membahas beberapa cerpen pilihan Kompas 2012-2015. Kajian tersebut menyimpulkan bahwa dalam teks-teks yang ditelaah, perempuan mencintai tumbuhan dan melakukan pengelolaan lingkungan. Perempuan juga ditampilkan kerap merindukan alam yang direpresentasikan oleh hujan dan sungai. Kajian ini juga mengungkapkan bahwa isu perempuan dalam bingkai ekofeminisme masih merupakan hal yang langka ditemukan di dalam karya fiksi. Tinjauan ekofeminisme juga digunakan dalam penelitian Prihasti dkk. (2017) untuk mengungkap mitos hubungan perempuan dengan alam dalam teks Opera Batak Perempuan di Pinggir Danau karya Lena Simanjuntak. Penelitian tersebut memperlihatkan adanya andil dari waktu dan kuasa dalam penciptaan mitos hubungan dengan alam. Fatimah dkk. (2019) mengungkap relasi alam dan perempuan dalam novel Chemistry Cinta di Wakatobi karya Dedi Oedji dengan perspektif ekofeminisme sosialis dari Karen J. Warren. Penelitian ini membuktikan adanya relasi antara alam dan perempuan yang tercermin dalam bentuk konservasi atau 
pemberian perlindungan, pemanfaatan, dan pelestarian terhadap alam, penjagaan ketahanan pangan, serta penguatan akses perempuan dalam pemanfaatan sumber daya alam.

Dari uraian terhadap penelitian-penelitian terdahulu, baik mengenai perjodohan maupun isu ekokritik dalam sejumlah teks tersebut, terungkap bahwa penelitian terhadap novel Dimi is Married belum dilakukan. Demikian pula dengan pembahasan terhadap kedua tema secara sekaligus, alasan lain dari pemilihan objek penelitian tersebut adalah belum banyaknya kajian dengan kritik sastra feminis terhadap karya-karya populer kontemporer bergenre metropop yang ditulis oleh perempuan. Dengan demikian, penelitian ini dapat dilanjutkan karena ada nilai kebaruan, baik dari segi objek kajian maupun kombinasi kedua tema sentral yang diusung. Tujuan yang dirumuskan untuk penelitian ini adalah mengungkap fenomena perjodohan dan isu ekokritik di dalam novel metropop Dimi is Married karya Retni SB.

\section{LANDASAN TEORI}

Makna perjodohan, dalam Tesaurus Bahasa Indonesia yang dikutip Kertanegara (2012: 2), adalah proses mengenalkan seseorang kepada lawan jenisnya dengan melalui perantara, baik melalui keluarga, teman, maupun medium lainnya. Dalam konteks budaya Indonesia, setidaknya ada tiga alasan perjodohan. Pertama, perjodohan untuk melanggengkan kekuasaan dan mempertahankan keningratan atau kemurnian keturunan, seperti yang terjadi pada keluarga kerajaan. Kedua, perjodohan dapat terjadi karena tuntutan ekonomi. Ketiga, perjodohan dilakukan dalam tradisi Islam yang dikenal dengan nama Ta'aruf.

Perbincangan tentang perjodohan tidak dapat dilepaskan dari konsep keluarga, yang menurut Goode (1991: 7) merupakan sistem masyarakat terpenting selain agama. Zulbaidah (2014: 1-2) menyatakan bahwa perjodohan adalah hal yang penting karena dalam sebuah perkawinan yang direstui orang tua, pasangan akan memperoleh keseimbangan hidup, baik secara biologis, psikologis, maupun secara sosial. Dalam tradisi budaya Jawa di Indonesia, menurut Rahayu (2016: 163), proses pemilihan pasangan melibatkan pertimbangan atas bibit, bebet, dan bobot. Bibit berarti asal usul atau garis keturunan. Calon pasangan harus jelas latar belakang keluarganya. Bebet berkaitan dengan kata bebedan atau cara berpakaian, yang menunjukkan kepribadian dan status sosialnya. Bobot artinya adalah kualitas diri, baik secara lahir maupun batin yang berhubungan dengan keimanan, pendidikan, pekerjaan, kecakapan, dan perilaku sang calon (Khansa, 2019: 36). Ketiga kriteria ini menunjukkan bahwa untuk membentuk keluarga baru harus dimulai dari memeriksa asalusul calon suami atau istri.

Dalam proses pemilihan pasangan yang dijodohkan, masalah agama, keyakinan, adat istiadat, dan latar belakang pun menjadi penting (Ningsih dan Handoyo, 2015: 1). Motif sebab perjodohan pada umumnya adalah hutang budi, kekerabatan, dan ekonomi, sedangkan motif tujuan perjodohan adalah untuk kepentingan pribadi dan kepentingan keluarga. Proses perjodohan biasanya dilalui dengan pembicaraan di antara keluarga untuk membahas kemungkinan menjodohkan masingmasing anak untuk mempererat hubungan kekerabatan. Apabila calon pasangan belum saling mengenal, maka keluarga laki-laki datang berkunjung ke rumah perempuan (Zulbaidah, 2014: 2).

Menurut perspektif feminis, gagasan tentang perjodohan seringkali tidak berpihak pada perempuan, sebagaimana dinyatakan Kertanegara (2012: 2-3). Perempuan selalu menjadi pihak yang harus patuh dan berperan sebagai objek dalam melanggengkan kekuasaan patriarki. Perempuan juga hampir selalu tidak memiliki hak untuk memiliki 
sendiri pasangan yang disukai atau menolak calon yang diajukan oleh orang tuanya. Kondisi bias gender ini, menurut Zulbaidah (2014: 24), akan mengarah pada pengaturan posisi tawar menawar yang tidak seimbang di antara laki-laki dan perempuan.

Permasalahan tentang perjodohan akan menarik jika dikaji melalui kritik sastra feminis karena menurut Culler dalam Sofia (2009: 20-21), pendekatan feminis memandang karya sastra dengan kesadaran khusus melalui tindakan reading as women 'membaca sebagai perempuan'. 'Pembaca perempuan' akan menemukan gambaran-gambaran konkret tentang kondisi perempuan sesuai dengan kenyataan yang ada. Mereka membaca, menginterpretasi, serta memahami tubuh perempuan dalam teks yang sekaligus adalah tubuh dan identitasnya sendiri. Dengan perspektif feminis, maka kajian ini dapat menyuarakan pemikiran dan gagasan perempuan dengan lebih lantang.

Selain kritik sastra feminis, pendekatan ekologi sastra atau kritik sastra ekologis digunakan dengan tujuan untuk meningkatkan kesadaran manusia terhadap situasi alam melalui karya sastra. Menurut Andriyani (2020: 86), teori sastra ekologis muncul di Barat pada awal tahun 2000an dan mulai berkembang di Indonesia setelahnya. Namun, kajian dengan landasan teoretis tersebut masih sangat terbatas. Aplikasi pendekatan ekokritik ini bertujuan untuk membuat pembaca memahami pesan tentang lingkungan yang ingin disampaikan pengarang.

Pendekatan ekokritik dalam karya sastra bertujuan untuk meningkatkan kesadaran manusia terhadap situasi alam melalui karya sastra. Pendekatan tersebut merupakan kombinasi atas metodologi sastra dan lensa ekokritik. Dalam kajian sastra, isu ekokritik merujuk pada pertanyaan seperti representasi alam dalam karya sastra, peran latar dalam alur novel, nilai-nilai yang sesuai dengan konsep ekologi di dalam novel, serta cara sastra mengubah hubungan umat manusia dengan alamnya (Ramadhani dan Sartuni, tanpa tahun: 5). Menurut Garrard yang dikutip Andriyani (2020: 86), konsep-konsep yang terkait dengan ekologi adalah (1) pencemaran, (2) hutan belantara, (3) bencana, (4) perumahan, tempat tinggal, (5) binatang, dan (6) bumi. Gagasan teoretis dari konsep ekologis tersebut adalah (1) melihat hubungan manusia dengan alam sekitar, (2) menganalisis gerakan wacana ekologi dalam mengungkapkan kehidupan yang harmonis, (3) menilai gerakan individu atau kolektif dalam pembentukan budaya ekologikal, (4) mengawal dan menyelaras dunia global, (5) meneliti pergolakan yang bersifat ekologikal, dan (6) menanamkan rasa cinta pada sesama ciptaan Tuhan.

Pada dasarnya, isu ekokritik tidak dapat dilepaskan dari kajian ekofeminisme, yaitu pemikian yang menghubungkan dominasi patriarki atas alam dan penindasan terhadap perempuan (Fatimah dkk., 2019: 3). Menurut Sanuniarti (2015: 231), perempuan dianggap lebih dekat dengan alam daripada laki-laki karena perempuan mempunyai natur bawaan yaitu berkarakter lebih peduli, membangun komunitas tanpa kekerasan, serta memiliki sensitivitas lebih tinggi pada lingkungan.

\section{METODE PENELITIAN}

Penelitian ini menggunakan metode deskriptif kualitatif. Pendekatan yang digunakan adalah kritik sastra feminis untuk membahas permasalahan tentang perjodohan dan pendekatan ekologi sastra untuk mengungkap isu ekokritik di dalam novel yang menjadi objek penelitian.

Objek penelitian yang dikaji adalah novel bergenre metropop berjudul Dimi is Married karya Retni SB. Novel setebal 384 halaman tersebut pertama kali dicetak tahun 2010 oleh PT. Gramedia Pustaka Utama, sedangkan yang menjadi objek penelitian ini adalah cetakan ke-4 tahun 2015. Selain Dimi is Married, karya pengarang tersebut 
yang terkenal di antaranya Cinta Paket Hemat (2007), His Wedding Organizer (2008), Pink Project (2009), My Partner (2012), Mencarimu (2014), dan Megamendung Kembar (2016).

Data berupa kata, frasa, dan kalimat dari novel yang berkaitan dengan permasalahan perjodohan dan isu ekokritik dikumpulkan dengan teknik simak catat setelah melalui pembacaan tertutup. Data selanjutnya diklasifikasi sesuai dengan permasalahan, kemudian diinterpretasi dan dianalisis dengan teori-teori yang relevan. Dari hasil kajian, dirumuskan kesimpulan untuk menjawab permasalahan penelitian yang berkaitan dengan fenomena perjodohan dan isu ekokritik di dalam novel metropop Dimi is Married karya Retni SB.

\section{PEMBAHASAN}

Pembahasan terdiri atas tiga bagian, yaitu ringkasan cerita novel Dimi is Married, telaah tentang wacana perjodohan, dan isu ekokritik yang terdapat di dalam metropop tersebut.

\section{Dimi is Married: Kisah Cinta Pasangan dari Dua Dunia}

Cerita dinarasikan oleh dua tokoh, yaitu Dimi dan Garda, yang dijodohkan oleh orang tua masing-masing yang saling bersahabat. Meskipun belum begitu mengenal Garda Hutama, Dimi Alea yakin pernikahan mereka akan berjalan baik. Garda tampil sebagai calon suami idaman yang baik hati, perhatian, romantis, dan diperkirakan mampu memenuhi seluruh kebutuhan calon istrinya. Namun, kedatangan Donna, mantan pacar Garda tiba-tiba menghancurkan harapan Dimi. Dimi baru menyadari bahwa pernikahan mereka tidak dirayakan dalam resepsi dan Garda tidak pernah memperkenalkannya pada orang-orang di sekitarnya. Sepertinya, laki-laki itu juga menyimpan rahasia.

Garda sebenarnya tidak berencana menikah namun menerima perjodohan tersebut karena tidak ingin ayahnya marah sehingga posisinya di perusahaan terancam. Terlebih lagi, Rio adiknya baru saja pulang dari luar negeri. Setelah mengetahui kebohongan Garda, Dimi pun meninggalkan Garda dan hidup sendiri di tempat kos. Ia juga berganti pekerjaan dari redaktur majalah tanaman menjadi reporter acara lingkungan hidup di sebuah stasiun televisi. Kepergian Dimi membuat Garda menyadari kesalahannya dan mencari istrinya itu yang dikabarkan hilang di belantara hutan Riau saat melakukan liputan.

Cerita yang terdiri dari 18 bab tersebut dinarasikan dengan alur progresif, bergerak cukup cepat terutama pada bagian-bagian akhir, dan tidak ditemukan adanya flashback. Hal ini menyiratkan bahwa visi menuju masa depan dianggap penting daripada mengingat kejadian-kejadian di masa lalu, sesuai dengan karakter para tokoh utama yang relatif muda dan bersemangat.

Secara bergantian, kedua tokoh utama, yaitu Garda dan Dimi, menjadi narator dari perjalanan hidup masing-masing sebelum dijodohkan, saat dijodohkan, dan setelah menikah. Permainan dua narasi berbeda yang digunakan oleh pengarang ini selain membuat pembaca dapat merasakan apa yang dialami oleh kedua narator secara mendalam dan juga menonjolkan karakter kedua tokoh utama. Pemisahan sudut pandang laki-laki dan perempuan juga mempertegas perbedaan perspektif di antara keduanya terhadap segala sesuatu. Narasi Garda tentang tentang Dimi awalnya negatif, namun lama-lama berubah menjadi lebih positif. Hal ini berbeda dengan Dimi yang sejak awal memandang Garda secara positif, kemudian menjadi negatif, lalu kembali positif. Seluruh pandangan ini menunjukkan bagaimana karakter maskulin dan feminin dipertentangkan.

Garda menjadi narator sebanyak 25 kali, sedangkan Dimi 23 kali. Proporsi jumlah narasi yang hampir sama, tetapi tetap saja berbeda. Hal ini menyiratkan adanya upaya pengarang untuk 
menjadi pihak 'netral' yang menampilkan sudut pandang laki-laki dan perempuan secara berimbang. Namun, pihak laki-laki seperti lebih diuntungkan karena bersuara lebih banyak. Terlebih lagi, narasi dari Gardalah yang membuka dan menutup cerita dalam novel Dimi is Married sehingga muncul kesan yang dominan bahwa laki-laki itulah narator yang sesungguhnya dari cerita tersebut.

Metropop ini menyajikan kota Jakarta sebagai latar yang ditunjukkan dengan nama-nama tempat serta sarana transportasi yang nyata, seperti daerah Kebon Jeruk, mall MOI, Muara Angke, bus Transjakarta. Latar sosial yang digambarkan melalui kehidupan para tokoh adalah kelas menengah ke atas. Para tokoh, terutama Garda dan keluarganya, ditampilkan sebagai keluarga yang sangat mapan sebagai pemilik perusahaan pulp dan kertas terbesar di Indonesia.

\section{"Jodoh kan di Tangan Tuhan”Versus Rasio- nalitas pada Era Milenial}

Perjodohan di dalam novel Dimi is Married diatur oleh kedua orang tua pasangan, yaitu orang tua Garda dan orang tua Dimi yang bersahabat di masa lalu. Motif perjodohan bukan terjadi karena alasan ekonomi atau agama yang disebutkan Kertanegara (2012: 2), melainkan sebagaimana yang terjadi pada para putri dan pangeran di masa lalu, yaitu untuk memastikan 'keningratan' dalam konteks modern. Ayah Garda ingin menjodohkan putranya yang selama ini kerap berpacaran dengan perempuan yang tidak sesuai standarnya, dengan perempuan 'baik-baik'. Perempuan yang dijodohkan dengan Garda tersebut adalah Dimi, putri sahabatnya di masa lalu yang dianggap memiliki karakter 'baik'.

"Malam ini kamu ikut Papa ke rumah Oom Harry. Dia punya anak gadis yang pasti berbeda dengan pacar-pacar ngacomu itu." $[\ldots]$

"Namanya Dimi. Manis, sopan, pintar, mandiri, berbakti dan sayang sama orang tua, dan banyak lagi hal-hal baik yang dia punya. Menurut Papa, perempuan jenis inilah yang cocok untuk jadi teman hidupmu. Supaya hidupmu tidak makin ngaco!" (SB, 2015: 11).

"Memang. Tapi kalau dilihat sekilas, kayaknya dia punya aura yang baik. Kita juga sudah kenal baik dengan orang tuanya. Jadi nggak mungkin kalau dia itu preman atau teroris? Zaman penuh tipu kayak gini, Dim, menilik latar belakang calon pasangan hidup jadi penting," papar Bunda serius. "Ini Bunda bukan lagi ngomong soal kekayaan lho ...” (SB, 2015: 35)

Sebagaimana dijelaskan Priyatna (2018: 129), ideologi patriarki membagi perempuan dalam dua kelas berbeda, yaitu perempuan jalang dan perempuan baik-baik. Penjenjangan ini telah mempertentangkan perempuan dalam arena yang telah dikuasai oleh laki-laki. Garda berperan sebagai subjek yang akan memilih perempuan sebagai objeknya.

Seperti yang dipraktikkan dalam perjodohan tradisional, pertemuan di antara Dimi dan Garda telah dipertimbangkan dengan matang, dengan merujuk pada bibit, bebet, dan bobot-nya. Tidak hanya keluarga Garda yang melakukan penimbangan melainkan juga keluarga Dimi.

Nah, mulailah episode saling memuji. Ini artinya, mereka yakin bahwa masingmasing adalah pribadi luar biasa yang padanya pantas untuk dipilih menjadi besan. Bahwa mereka tak keberatan jika anak-anak mereka diikat dalam satu perkawinan. Soal bobot bibit dan bebet toh sudah tak perlu lagi dipikirkan! (SB, 2015: 22)

Dalam pandangan orang tua, perjodohan seringkali menjadi lebih baik daripada autonomous marriage yang didasari oleh keinginan anak belaka. "Fakta sudah membuktikan. Anak zaman sekarang kalau cari jodoh sendiri, hasilnya banyak yang kawin- 
cerai. Hasil dari perjodohan justru lebih bisa dipertanggungjawabkan. Langgeng sampai tua.” (SB, 2015: 10) Keyakinan atas pandangan tersebut menunjukkan bahwa generasi orang tua Dimi dan Garda pun telah mengalami perjodohan sehingga mereka berani menjamin keberhasilannya.

Perjodohan pada umumnya diberlakukan pada dua keluarga yang berelasi homogen, bermakna memiliki lebih banyak kesamaan dibandingkan perbedaan. Namun, dari narasi diketahui bahwa keluarga Digdo Danurakarsa, ayah Garda, merupakan pemilik perusahaan industri pulp dan kertas terbesar di Indonesia, sedangkan keluarga Harry, ayah Dimi merupakan seorang dosen. Kedua laki-laki paruh baya yang pernah bersahabat di masa muda tersebut dapat dikatakan tidak berada pada strata sosial yang setara. Keluarga Garda sangat kaya raya, sedangkan keluarga Dimi biasa-biasa saja.

Garda sebagai laki-laki tampan, mapan, sangat percaya diri, dan pernah berpacaran dengan banyak perempuan, tidak memandang perjodohan sebagai hal yang sesuai dengan keinginannya. Ia merasa masih belum perlu untuk menikah di usianya yang ke-31 tahun. Namun, ia terpaksa menurut pada keinginan ayahnya demi mendapatkan posisi utama sebagai penerus kepemimpinan di keluarganya. Ia takut bila melawan kehendak orang tuanya, posisi tersebut akan diberikan pada sang adik, Rio. Dengan demikian, motif perjodohan dari sudut pandangnya adalah ambisi meraih kekuasaan.

Aku dipaksa menikah! Dengan perempuan yang bukan pacarku!

Sekali lagi, menikah dengan perempuan yang bukan pacarku. Tahu apa artinya? Iyalah, jika ada perempuan yang tak memenuhi selera dan kriteriaku untuk dijadikan pacar, sudah tentu perempuan itu punya nilai di bawah standar. Tidak cantik, tidak mulus, tidak gaul, tidak modis, tidak cemerlang, tidak kelas, dan tidak segalanya. (SB, 2015: 6)

Di sisi lain, Dimi, sang narator-tokoh perempuan, memandang perjodohan sebagai hal yang "sungguh-sungguh-teramat-sangat menggelikan!" (hal. 33). Sebagai perempuan yang aktif, mandiri secara finansial, dan baru berusia 23 tahun, ia tidak merasa terdesak untuk bersegera menikah, terlebih dengan seorang laki-laki yang tidak dikenalnya.

Ha, siapa bisa menolak, kan? Ini kesempatan langka yang tak mungkin bakal datang dua kali!

Kalau aku jadi kawin dengan Garda, huuu ... sudah pasti mulut teman-temanku bakal ternganga selebar nyiru karena tak percaya pada keberuntunganku. [...] Dan mantan pacar-pacarku pasti akan meringis menyesal karena ternyata seorang Garda (Dengan dukungan penuh orang tuanya yang hebat itu) meyakini bahwa aku adalah cewek paling sempurna di dunia. (SB, 2015: 32)

Namun, ada pertimbangan lain yang membuatnya menerima lamaran dari keluarga Garda. Dimi jatuh cinta pada laki-laki tersebut sejak pertemuan pertama mereka, dan yang utama, ia tidak ingin mengecewakan kedua orang tuanya yang tampak berharap memiliki menantu seperti Garda. Bagaimanapun Dimi tetap mencoba menebak-nebak motif yang sesungguhnya dari perjodohan mereka karena relasi di antara mereka benar-benar tidak homogen. Ia memahami bahwa situasi kekayaan dan status sosial keluarga mereka sangat berbeda.

Apa Ayah nggak merasa aneh dan heran? Masa sih orang seperti mereka sempatsempatnya datang ke sini dengan membawa rencana perjodohan yang mencengangkan itu? Sudah seharusnya kita curiga. Jangan-jangan mereka sedang ingin menutupi aib. Siapa tahu Garda gay. Siapa tahu dia punya kelainan psikologis. Siapa tahu dia pemakai drugs level tinggi. Siapa 
tahu dia pemakan darah komodo. Siapa tahu dia sudah divonis mandul. Mereka hanya sedang memerlukan status ..."

"Dimi!" sentak Ayah. Pasti terkejut dengan analisaku yang mungkin vulgar. (SB, 2015: 65)

Dalam perjalanan rumah tangga mereka yang tidak harmonis, Dimi dan Garda pun saling menjauh, meskipin keduanya tidak terburu-buru untuk bercerai. Masih ada pertimbangan untuk menjaga perasaan kedua orang tua masing-masing sebagai alasan dari kesepakatan mereka saat dijodohkan.

\section{Perempuan dan Femininitasnya dalam Isu Ekokritik}

Novel Dimi is Married terindikasi memuat isu ekokritik dengan ditemukannya elemen-elemen ekologi dalam konsep Garrard yaitu hutan belantara, bencana, binatang, dan bumi. Permasalahan berkaitan dengan hutan belantara merupakan isu yang paling banyak dibahas karena sangat berhubungan dengan jalannya cerita. Garda adalah putra pemilik Utamaraya, sebuah perusahaan pulp dan kertas terbesar di Indonesia, yang membutuhkan bahan baku untuk pembuatan kertas dan produk lainnya. Dimi sendiri merupakan reporter acara bertema lingkungan hidup yang sedang bertugas meliput sengketa status hutan di antara masyarakat lokal Riau dan Utamaraya.

Berbeda dengan Garda yang memiliki ambisi dan kinerja tinggi di bidang bisnis pulp dan kertas, sejak kuliah dan bekerja, Dimi telah menunjukkan ketertarikan pada dunia flora dan fauna. Ia berbeda dengan perempuan cantik pada umumnya dalam 'standar' Garda, yaitu mereka yang gemar pergi ke mall lalu berkutat dengan fashion, make up, perhiasan, dan lain-lain. Dimi sendiri lebih menyukai kegiatan di alam terbuka dan bersentuhan dengan tumbuhan.
"Dimi masih sibuk di majalah soal tanaman itu, Har?” tanya Papa.

"Begitulah, dia masih suka keluar-masuk taman-kebun-hutan. Menulis tentang rumput, bunga liar, pohon, mata air, tumbuhan langka, dan sejenisnyalah. Kalau pas libur, dia suka sibuk bikin filmfilm dokumenter dengan kawan-kawannya. Katanya, mumpung belum kawin, jadi bisa ikut kegiatan-kegiatan macam itu.” (SB, 2015: 23)

Keinginan Garda untuk menjadi direktur utama di perusahaan kertas ayahnya menunjukkan cara berpikir maskulin yang dicirikan oleh kecenderungan agresif, kompetitif, dan dominatif. Karakter tersebut berlainan dengan Dimi yang ditampilkan feminin, dengan sifat intuitif, senang berkoordinasi dan bekerja sama, serta condong memelihara dan merawat.

Karakter yang dilekatkan pada perempuan tersebut dimanfaatkan dalam banyak acara televisi, yang kerap mengobjektifikasinya sebagai host untuk membawakan liputan karena penampilan yang cantik dan menarik. Citra perempuan yang dibangun dalam media memang disesuaikan dengan kebutuhan pelaku bisnis (Nayahi, 2015). Namun, tidak demikian halnya dengan Dimi yang tampil kasual dan apa adanya, sehingga perannya menjadi lebih berkesan wajar dan natural. Posisinya sebagai pembawa acara lingkungan hidup pun menuntutnya untuk beradaptasi dengan kondisi situasi lingkungan yang tidak selalu aman dan menyenangkan, seperti yang dilakukannya saat menyusuri sungai Ciliwung untuk meliput berita tentang sampah yang menjadi penyebab banjir (hal. 232).

Wajahku sudah muncul di televisi, satu minggu satu kali, sebagai host acara Sibak. Di acara ini tentu saja aku tidak tampil "sengaja dibuat cantik". Aku justru tampil alami, sebenarnya khasku. Celana kargo, kaus oblong bergambar unik, ransel, topi, 
dan sepatu kets. Rambut sebahuku yang kriwil, kadang digerai saja, kadang diikat ekor kuda, dengan peluh yang sering kali dibiarkan tampak. Meski begitu, aku tidak diposisikan sebagai cewek garang atau mengesankan perempuan tangguh. Karakterku adalah cewek biasa yang bisa peduli lingkungan, tanpa harus tampil keras. (SB, 2015: 233-234)

Dimi tidak turun langsung dalam melakukan gerakan perawatan dan perlindungan alam, tetapi profesinya sebagai reporter acara lingkungan memberinya peluang untuk menyampaikan kepada penonton realita tentang alam yang dirusak oleh manusia. Ia mengabarkan bencana sebagai pengingat agar pemirsa memahami betapa kritisnya situasi lalu turut serta mengambil bagian dalam pelestarian bumi.

Aku sudah meliput sungai yang tercemar, desa yang sehari-hari dihujani abu kapur akibat kegiatan pabrik semen, terumbu karang yang rusak, kubangan-kubangan raksasa yang menyedihkan di bekas areal pertambangan, abrasi pantai, dan lain-lain sejenis itu. Hal-hal yang memang sudah menjadi perhatianku sejak dulu. Jadi, aku senang bisa membawakannya dan mengabarkannya kepada publik, betapa sudah parah ketidakpedulian kita terhadap bumi dan segenap makhluk pengisinya. Misi kami, tentu saja adalah perubahan. Berharap manusia bisa lebih arif memperlakukan alam tempatnya menumpang hidup. (SB, 2015: 234)

Kontribusi tokoh perempuan dalam hal ini adalah menjadi wakil dalam menyuarakan alam serta penduduk desa sebagai pihak yang paling dirugikan oleh modernisasi. Alam dieksploitasi secara besar-besaran tanpa diiringi usaha yang memadai untuk mengantisipasi dampak kerusakan yang sulit dikendalikan. Cara pandang manusia terhadap alam yang saat ini cenderung mekanistik merupakan derivasi dari cara berpikir eksploratif dan menjurus pada kapitalistik (Mulyani, 2017: iii).

'Yah, pemirsa ... peristiwa ini bukan kali ini saja terjadi. Tapi sudah puluhan kali. Korban sudah banyak. Bukan hanya rumah dan ladang, tapi juga jiwa. Tercatat, sejak tahun 2000 ... sudah sebelas nyawa manusia melayang dan tiga puluh satu gajah tewas akibat konflik ini. Perang gajah dan manusia ini sungguh tak perlu terjadi jika kita tidak mengurangi habitat mereka secara membabi buta atas nama kepentingan-kepentingan komersial," tutur Dimi lugas, dengan suara jernihnya yang kukenal itu. (SB, 2015: 240)

Dari seluruh elemen yang terlibat, pihak industrilah yang paling harus bertanggung jawab atas kerusakan alam. Dalam pandangan ekofeminisme, sebagaimana dijelaskan Candraningrum, kultur patriarki tidak hanya berkembang di dalam budaya sosial melainkan juga dalam konteks pelestarian alam (Yusmarani, 2019: 64). Dunia usaha dan industri merupakan representasi dari patriarki yang memandang perempuan, dan juga alam, sebagai objek dan properti yang selayaknya dieksploitasi.

Sebab aku sungguh prihatin dengan nasib hutan-hutan alam di lahan gambut ini. Dalam 25 tahun terakhir saja, Riau sudah kehilangan 65 luas hutannya. Hutan alam yang begitu kaya dengan keanekaragaman hayati, dalam waktu sangat singkat sudah digunduli, untuk kemudian menjadi hutan kayu untuk bahan baku pulp, kelapa sawit, jarak pagar, dan kini perkebunan kayu untuk energi biomassa. Ck ck ck, mengapa mereka tak mengerti bahwa lahan gambut ini cukup dalam dan sangat kaya karbon? Apa mereka tak mengerti apa akibat dari pembabatan ini? Bagaimana mereka bisa santai menghadapi ancaman perubahan iklim global yang bisa sangat dahsyat? (SB, 2015: 293) 
Permasalahan status hutan pun seperti sengaja dibuat oleh pihak-pihak tertentu untuk mengelabui masyarakat. Dimi menyadari bahwa liputannya di hutan alam Riau bersinggungan dengan perusahaan Utamaraya milik ayah Garda. Ia pun berusaha untuk objektif sekaligus tidak terlibat terlalu dalam pada konflik rakyat setempat. Rasionalitasnya sebagai perempuan menahannya untuk tidak menghakimi satu pihak dengan pernyataan "ada kemungkinan ... aku tak tabu bagaimana persisnya" dan bukan 'sudah pasti Utamaraya yang bersalah", terlebih pihak yang diposisikan bersalah oleh pandangan umum adalah pihak keluarga suaminya.

Jadi ada kemungkinan, hutan-hutan rusak yang telah kami soroti itu adalah hasil karya Utamaraya. Meski aku tak tahu bagaimana persisnya. Sebab hutan-hutan itu adalah hutan alam, bukan HTI atau hutan rakyat yang menjadi mitra bagi pabrik. Hutan alam itu tidak bertuan (sebenarnya bumi itu sendirilah yang menjadi tuannya), dibalak secara liar oleh pihak-pihak yang tak bertanggung jawab. $[\ldots]$

"Kita bisa ngangkat soal perseturuan antara masyarakat adat dengan pengelola hutan yang ada di kecamatan ujung sana. Dengar-dengar, konfliknya lumayan panas. Udah ada korban tewas dari masyarakat setempat ..." (SB, 2015: 282-283)

Pada saat mengalami penculikan, Dimi dapat menyelamatkan diri berkat kepercayaan para penculiknya, yang merupakan warga setempat, kepada mitos dan larangan untuk memasuki hutan saat malam. Di Indonesia, memang ditemukan sejumlah mitos yang dibuat oleh manusia dengan tujuan untuk melindungi hutan dan sumber air. Namun, dalam mitos-mitos tersebut, perempuan sering ditempatkan pada posisi korban sebagaimana mereka yang sedang mengalami menstruasi dilarang masuk hutan, mandi di sungai, atau memetik tanaman tertentu. Perempuan juga bahkan kerap ditampilkan sebagai 'penunggu' hutan. Menurut Warren, kedekatan perempuan dengan alam ini terjadi karena sifat femininnya (Prihasti dkk, 2017: 153).

Sebenarnya, dalam hati aku jadi bertanyatanya. Memangnya ada apa sih dengan "keangkeran hutan" ini dan "menstruasi perempuan"? Apa hal ini berkaitan dengan legenda, mitos, sejarah masa lalu, atau memang ada beberapa pengalaman empirik yang secara kebetulan telah menegaskan mitos itu? [...]

"Mencuci darahmu di sungai?! Celaka dua belas! Jangan! Roh tetua bisa ngamuk dan tak membiarkan kita keluar dari hutan ini hidup-hidup!" raung seorang. (SB, 2015: 349)

Kedekatan perempuan dengan lingkungan terjadi salah satunya adalah akibat dari realita historis perempuan sebagai korban kerusakan lingkungan. Deforestasi, misalnya berdampak pada rusaknya hutan dan hilangnya sumber daya yang biasa dimanfaatkan perempuan (Mulyani, 2017: v).

Selain tentang hutan, elemen ekokritik yang dibahas dalam novel Dimi is Married adalah binatang, yang terdiri atas gajah dan harimau Sumatera yang keberadaannya semakin langka. Sementara itu, solusi yang ditawarkan dari permasalahan kayu sebagai bahan baku kertas adalah penggunaan bahan baku alternatif seperti tandan kosong sawit dan ampas tebu (hal. 378). Pilihan ini dapat menjadi salah satu upaya penyelamatan hutan alam yang ditawarkan oleh pengarang.

Selain pengajuan solusi atas eksploitasi hutan untuk industri pulp kertas, penyelesaian kasus penculikan Dimi menjadi jalan keluar dari kerumitan hubungannya dengan Garda. Pertemuan mereka di hutan mengurai konflik percintaan yang telah terjadi dan mereka pun selanjutnya hidup bahagia selamanya. 


\section{PENUTUP}

Penelitian ini menunjukkan bahwa setidaknya ada dua tema utama di dalam novel Dimi is Married, yaitu perjodohan dan isu ekokritik. Perjodohan yang terjadi di antara tokoh utama Dimi dan Garda diperantarai oleh kedua orang tua masing-masing dengan motif menjaga "keningratan" dalam konteks modern. Perjodohan dilakukan dengan menerapkan pertimbangan atas kriteria tradisional, yaitu bibit, bebet, dan bobot. Standar perempuan yang diinginkan sebagai calon istri adalah yang sesuai dengan stereotipe peran gender, yaitu manis, sopan, patuh, dan sayang pada orang tua. Permasalahan dalam perjodohan terjadi karena relasi yang tidak homogen berkaitan dengan alasan menikah, status sosial, dan pandangan hidup. Isu ekokritik yang dibahas dalam novel melibatkan elemen hutan, bencana, binatang, dan bumi. Perempuan menyuarakan kerusakan alam dan kerugian yang dialami rakyat lokal akibat pengelolaan industri yang abai pada lingkungan. Dalam pandangan feminis, ideologi patriarki bekerja melalui perlakuan-perlakuan kepada alam yang menyerupai tindakan pada perempuan, yaitu sebagai objek eksploitasi. Hasil kajian ini sejalan dengan penelitian terdahulu dari Wicaksono dan Abadiyah, bahwa perjodohan kerap mendatangkan konflik di dalam rumah tangga akibat kurangnya masa orientasi di antara pasangan yang dijodohkan. Dalam konteks ekokritik, hasil penelitian ini menyepakati kajian terdahulu dari Ahmadi, Prihasti, dan Fatimah, bahwa ada kelindan di antara alam dan perempuan yang diasosiasikan melalui karakter feminin yang bersifat merawat.

Hasil penelitian tersebut berimplikasi pada berkembangnya gagasan bahwa dalam metropop sekalipun, yang pada umumnya ditulis oleh perempuan dan dibaca oleh perempuan, masih terdapat ide-ide yang justru tidak terlalu berpihak pada perempuan. Sebelumnya, peneliti mengharapkan dalam novel yang dikaji, ada gagasan- gagasan progresif yang condong menempatkan perempuan pada posisi yang seharusnya, yaitu sederajat dengan laki-laki. Dalam novel Dimi is Married terungkap bahwa perempuan, seperti juga alam, selalu diposisikan sebagai subordinat, korban, berkarakter patuh, dan harus menurut pada kehendak pihak yang dominan (laki-laki). Sekalipun muncul fenomena resiliensi dan perlawanan, tetapi hal tersebut tidak dapat dinilai memadai karena pada akhirnya, perempuan digambarkan menyepakati opresi (perjodohan) yang ditimpakan padanya dan bersedia untuk bernegosiasi dengan tujuan mendapatkan kehidupan rumah tangga yang secara normatif lebih nyaman.

\section{DAFTAR PUSTAKA}

Abadiyah, Saadatul. (2020). "Resolusi Konflik Perjodohan dalam Novel Hati Subita Karya Khilma Anis." Jurnal Penelitian, Pendidikan, dan Pembelajaran. Vol. 15, No. 24, 1-23.

Ahmadi, Anas. (2017). "Feminitas, Ekofeminisme, dan Cerpen Indonesia.” Totobuang. Vol. 5, No. 1, 163-174.

Andriyani, Noni. (2020). "Kritik Sastra Ekologis dalam Drama-Drama Terbaru Indonesia." Jurnal Sastra Indonesia. Vol. 9, No. 2, 85-89.

Andriyani, N. dan Piliang, Wilda S.H. (2019). "Kritik Sastra Ekologis terhadap Novel-novel Terbaru Indonesia." Geram (Gerakan Aktif Menulis). Vol. 7, No. 1, 81-89.

Deona, H.M. (2019). "Analisis Cerita Romance Populer Cinta Abadi dan Pria, Wanita, dan Anak Karya Erich Segal.” Jurnalistrendi: Jurnal Linguistik, Sastra, dan Pendidikan. Vol. 4, No. 1, 321-331.

Fatimah, Andi A.B., Juanda, Faisal. (2019). "Relasi Alam dan Perempuan dalam Novel Chemistry Cinta di Wakatobi Karya Dedi Oedji Melalui Pendekatan Ekofeminisme." bttp:// 
eprints.unm.ac.id/13214/ diakses tanggal 19 November 2020.

Fiksimetropop. (2014). “[Suka nggak suka] Tema Perjodohan." http:// www.fiksimetropop.com/2014/10/sukanggak-suka-tema-perjodohan.html diakses tanggal 20 November 2020.

Fitriana, A. (2010). "Karakteristik Novel-Novel Metropop Gramedia." Skripsi. Universitas Indonesia, Depok.

Goode, W. J. (1991). Sosiologi Keluarga (Penerjemah D.L Hasyim). Jakarta: Bumi Aksara.

Kertanegara, Rizky. (2012). "Perjodohan di Ruang Publik (Kajian Resepsi Perjodohan di Ruang Publik dalam Program Take Me Out di Indosiar oleh Remaja Perempuan)." https:// www.researchgate.net/publication / 333668201_PERJODOHAN_DI_RUANG_PUBL IK_ STUDI_RESEPSI_PEREMPUAN_INTEI EKTUAL_ TERHADAP_PROGRAM_TAKE_ME_OUT_ DI_INDOSLAR diakses tanggal 19 November 2020.

Khansa, L, A. (2019). "Makna Tradisi Bibit, Bebet, dan Bobot pada Pernikahan Adat Jawa dalam Film (Analisis Semiotika pada Film Prospective Son-in-Law karya Fajar Arrachman)." Skripsi. Universitas Muhammadiyah Malang, Malang.

Mulyani. (2017). Ekofeminisme: Perempuan dan Permasalahan Lingkungan. Sidoarjo: Indomedia Pustaka.

Nayahi, Manggala. (2015). “Objektifikasi Perempuan oleh Media: Pembakuan Identitas Perempuan dan Dominasi Kekuasaan Lakilaki." http:// www.jurnalperempuan.org/wacanafeminis/objektifikasi-perempuan-oleb-mediapembakuan-identitas-perempuan-dan-dominasikekuasaan-laki-laki diakses tanggal 21 November 2020.
Ningsih, E.Y. dan Handoyo, P. (2015). "Perjodohan di Masyarakat Bakeong Sumenep Madura (Studi Fenomenologi tentang Motif Orang tua Menjodohkan Anak)." Paradigma. Vol. 3, No. 3, 1-5.

Prihasti W., Elly, Udasmoro, W., Simatupang, L.L. (2017). "Negosiasi Mitos Hubungan Perempuan dengan Alam dalam Teks Opera Batak Perempuan di Pinggir Danau Karya Lena Simanjuntak (Tinjauan Ekofeminisme)." Lingua. Vol. 13, No. 2, 151-165.

Priyatna, A. (2018). Kajian Budaya Feminis Tubuh, Sastra dan Budaya Pop. Yogyakarta: Arti Bumi Intaran.

Putra, C. R. W. dan Sugiarti. (2019). "Ekologi Budaya dalam Novel Lanang Karya Yonathan Rahardja." Atavisme. Vol. 22, No. 1, 113-127. Ramadhani, A.Y. dan Sartuni, R. (tanpa tahun). "Relasi Antara Manusia dan Lingkungan Hidup dalam Novel Patrikel Karya Dewi Lestari: Sebuah Kajian Ekokritisisme.” bttp:/ /www.lib.ui.ac.id/naskabringkas/2016-03/ S46846-Alfi\%20Yusrina\%20Ramadhani diakses tanggal 19 November 2020.

Rahayu, L. M. (2016, 26 Juli 2016). Perempuan dan Perkawinan dalam Tradisi dan Konstruksi. Paper presented at the Seminar Nasional Sastra dan Budaya: Perempuan dan Lokalitas, Fakultas Ilmu Budaya Universitas Padjadjaran.

Sanuniarti, V. V. (2015). "Boenthelan sebagai Upaya Mengurangi Sampah Kantong Plastik: Kajian Ekofeminisme." Jurnal Lingkungan dan Pembangunan. Vol. 1, No. 3, 227-239.

SB, Retni. (2015). Dimi is Married (Cetakan Keempat). Jakarta: PT. Gramedia Pustaka Utama.

Sofia, Adib. (2009). Aplikasi Kritik Sastra Feminis Perempuan dalam Karya-karya Kuntowijoyo. Yogyakarta: Citra Pustaka. 
Sugiarti. (2017). "Kajian Ekobudaya pada Novel Tirai Menurun Karya NH. Dini." Atavisme. Vol. 20, No. 1, 110-121.

Ulya, H., Khoirunnisa, Chamalah, E. (2020).

"Ecocritism in Sepotong Senja untuk Pacarku by Seno Gumira Ajidarma." Aksis: Jurnal Pendidikan Bahasa dan Sastra Indonesia. Vol. 4, No. 1, 144-152.

Wicaksono, Rendra. (2015). "Masalah Perjodohan dalam Novel Memang Jodoh karya Marah Rusli (Kajian Sosiologi Sastra)." Skripsi. Universitas Pendidikan Indonesia, Bandung,
Yusmarani, Ririeh. (2019). Ecofeminism Perspective on Indonesian Literary Works. ISLL AC: Journal of Intensive Studies on Language, Literature, Art, and Culture. Vol. 3, No. 1, 63-68.

Zulbaidah. (2014). "Dampak Perjodohan Pilihan Orang Tua di Gampong Geulanggang Gajah Kecamatan Darul Makmur Kabupaten Nagan Raya." Skripsi. Universitas Teuku Umar. 